\title{
Culture and Rural Resettlement Projects in Laos
}

\author{
Phonevilay Sinavong ${ }^{1}$ \\ ${ }^{1}$ Graduate School of International Development, Nagoya University, Japan \\ Correspondence: Phonevilay Sinavong, Graduate School of International Development, Nagoya University, \\ Furo-cho, Chikusa-ku, Nagoya 4648601, Japan. E-mail: lanoysinavong@gmail.com
}

Received: May 28, 2013 Accepted: June 20, 2013 Online Published: September 2, 2013

doi:10.5539/ach.v6n1p1 URL: http://dx.doi.org/10.5539/ach.v6n1p1

\begin{abstract}
Laos is linguistically and ethnically the most diverse country in mainland Southeast Asia. To build a sustainable community/village with multi-ethnicity, it is necessary to take a pro-cultural consideration in the process of development intervention by the government. As a case study of resettlement associated with hydroelectric power development, this paper aims at clarifying the cultural elements adopted practically in the implementation of resettlement associated with hydroelectric power development and the sense of value behind such cultural elements. Using qualitative and quantitative approaches by sample surveys, the results show that the cultural elements such as symbol, hero, ritual and belief have played a practical and significant role in the consensus formation during the consultation \& planning and physical relocation processes. However, among ethnic groups the degree of senses of value related to symbol, ritual and belief is different while the degree of sense of value related to hero is the same.
\end{abstract}

Keywords: culture, ethnicity, sense of value, rural resettlement, Laos

\section{Introduction}

Laos is linguistically and ethnically the most diverse country in mainland Southeast Asia with $65.8 \%$ of the whole country's population residing in rural areas in 2011 (Asian Development Bank [ADB], 2012). The latest official classification (2005) has categorized the Lao population, as being comprised of 49 ethnic groups, into four ethno linguistic families: Lao-Tai (eight ethnic groups), Mon-Khmer (32 ethnic groups), Sino-Tibetan (seven ethnic groups), and Hmong-Mien (two ethnic groups) (Laos, 2005b). In 2005, the population of Lao-Tai who arrived before the 13th century covered $65 \%$ of the population; Mon-Khmer who arrived around the 15th century covered $23 \%$; Sino-Tibetan who arrived in the late 18th century covered 3\%, and Hmong-Mien who arrived in the 19th and early 20th centuries covered 8\% (Chazée, 1999; Laos, 2005b).

In 1989, the 1st National Conference on Forestry of Laos adopted the government plan to implement permanent resettlements of a quarter of the country's population by the year 2000 (Evrard \& Goudineau, 2004). The initiative of resettlement policy was formed to achieve five objectives: 1) access and service delivery, 2) opium eradication, 3) reduction of security concerns, 4) eradication of swidden farming, and 5) cultural integration and national building, with three resettlement instruments: focal site, village consolidation, and land and forest allocation (Baird \& Shoemaker, 2005). Evrard and Goudineau (2004) argued the resettlement is a double process: deterritorialization- leaving territory and changing whole traditional way of life; and reterritorializationsetting in a new environment and accepting and integrating into the cultural preferences. However, this is difficult in practice due to the diversity of ethnicity with rich cultures and traditions.

Meanwhile, in the 1980s, hydroelectric power development in Laos started when the World Bank (WB), ADB, United Nations Development Program (UNDP), and bilateral westerners advised Laos to develop its hydropower resources and sell the power to Thailand since it was the only option for Laos to fuel its economic development (International River, 1999). From the late 1980s to the early 1990s, the International Monetary Fund (IMF), WB, ADB, and dam construction consultants flocked to Laos after the Government of Laos (GoL) promulgated its foreign investment code in 1988(Ibid). According to the Lao PDR Development Report 2010, there were 153 hydropower projects at four stages: operational stage (nine projects), under construction (nine projects), in planning (26 projects), feasibility study (46 projects), and status unclear, of which there is as yet, no Memorandum of Understanding, (63 projects). World Bank (2010) estimated that around 100,000 to 280,000 people in the country would be resettled as a direct result of hydropower in Laos (WB, 2010). These people are 
among the poorest households and likely to be illiterate and non Lao-Tai ethnic group (EU, 2011).

Therefore, GoL is facing a big challenge to boost economic development forward through hydroelectric power and minimize negative impacts on rural people with diverse cultures. Currently, GoL is attempting to improve the policy receiving support from international organizations such as ADB and WB. As a result, GoL issued first the Decree on Compensation and Resettlement which emphasized the requirement of sensitivity to culture during the implementation of the development project on 7 July, 2005. The Article 11(Local Culture \& Practices) in the Decree on Compensation and Resettlements states, "During planning, construction and operation periods, project owners shall consider local cultural and religious properties, practices and beliefs". In addition, ADB formulated the "Ethnic Minority Development Framework" in September, 2008", (ADB, 2008).

Instead of delivery of development to its people, GoL is bringing people to development as well as planning to achieve cultural integration, i.e. persuading minority ethnic groups to adopt dominant ethnic groups such as Lao ethnic group through resettlement. Achieving this is difficult in practice due to the diversity of ethnicity with rich cultures and traditions. Previous researches (Chamberlain, 2007; Daviau, 2006; EU, 2011; Evrard \& Goudineau, 2004; Lyttleton, Cohen, Rattanavong, Thongkhamhane, \& Sisaengrat, 2004) showed that social and cultural conflicts have occurred in the resettlement sites in the past decade and that more resettlements would occur in the near future due to the state development plan. To build a community/village with diversity of ethnicity, it is first necessary to understand how the cultural consideration can be appropriately taken into account in the development intervention by the government. Therefore, the objectives of this paper are to clarify (1) the cultural elements adopted practically in the implementation of resettlement associated with hydroelectric power development and (2) the sense of value behind such cultural elements.

\section{Materials and Methods}

\subsection{The Concept of Culture and Its Measurement}

According to the Oxford dictionary (7th edition), culture refers to customs and beliefs, art, way of life, and social organization of a particular country or group. Culture is produced in two different ways: in the experiences of everyday interactions themselves or by specialized culture-producing organization (Collins, 1985). According to the organizational anthropologist Hofsted (2010), the total concept of culture is inhered in four different levels of depth, i.e. symbols-worlds, gestures, pictures, or objects that carry a particular meaning only recognized as such by this share the culture; heroes-persons, alive or dead, real or imaginary, who possess characteristics that are highly prized in a culture and thus serve as models for behaviour; rituals-collective activities, technically superfluous to reaching desired ends, but within a culture are considered as socially essential; and values-broad tendencies to prefer certain states of affairs over others.

As it is discussed above, the various definitions to describe "culture" are complex, and it is not easy to comprehend by using a single definition. However, as to cultural differences, it is common to start measuring the value which is the core of culture. Currently, there are a limited numbers of literatures on cultural studies on Lao society, particularly on people's values. A cultural study on Thailand, which is similar to Laos in terms of language, beliefs, and lifestyle, is a valuable reference for this study. To measure values of Thai people, Komin (1991) replicated the procedures used by Rokeach (1967 through 1971) using a ranking approach. This approach was proved generally reliable and valid in cross-cultural researches (Shawyun \& Tanchaisak, 2006). In Komin's Thai Value Survey (1991), the instruction to respondent was to "arrange values in the two lists of instrumental and terminal values in order of importance to You, as guiding principles in YOUR life." However, the procedure of measuring values by Komin (1991) has some limitation when the respondents are illiterate.

It is acceptable to measure culture in an indirect way via values which are already proved by many previous studies above. However, some values existing in a country may not exist in another and/or may duplicate in other countries. The 43 values stated by Komin (1991) based on Thai society are localized to 36 values (Table 1) through the preliminary survey, to study on cultural differences of rural people in Laos. In this study, the rating approach through the structured interview was implemented instead of ranking by respondents because almost all villagers had a difficulty in understanding the questions. 
Table 1. List of values used in the survey

\begin{tabular}{|c|c|}
\hline Code & Values \\
\hline $\mathrm{V}_{1}$ & $\begin{array}{l}\text { Brotherhood spirit \& Interdependent, mutually helpful, Kind-helpful (Being kind and help others without } \\
\text { expecting anything in return; Depend on each other, being helpful to each other; Be kind, empathizing, and } \\
\text { ready to help others. Be nurturing, kind, and soft to others.) }\end{array}$ \\
\hline $\mathrm{V}_{2}$ & Social recognition (Being popular, respected, and highly regarded in the society) \\
\hline $\mathrm{V}_{3}$ & An exciting life (Having a colorful, exciting and adventurous life) \\
\hline $\mathrm{V}_{4}$ & $\begin{array}{l}\text { A comfortable life \& status-wealth (Being rich, having wealth and helpers obtained through money; Being } \\
\text { successful in one's job; Having job, money, sufficient wealth, and good health.) }\end{array}$ \\
\hline $\mathrm{V}_{5}$ & True friendship (Having true and loyal friends who understand us.) \\
\hline $\mathrm{V}_{6}$ & $\begin{array}{l}\text { Mature love with the same ethnicity (Having true love and true understanding with opposite sex partner } \\
\text { within ethnicity) }\end{array}$ \\
\hline $\mathrm{V}_{7}$ & Religious-spiritual life to guide in a living (Having high moral standard and religiously grounded mind.) \\
\hline $\mathrm{V}_{8}$ & Social relation (Having good human relations and be accepted in social work.) \\
\hline $\mathrm{V}_{9}$ & A beauty and abundance of nature (Being an appreciator of the nature) \\
\hline $\mathrm{V}_{10}$ & Wisdom-knowledge (Being satisfied with knowledge, experience, and wisdom.) \\
\hline $\mathrm{V}_{11}$ & Self-esteem (Having one's pride; being pride and maintain self-values.) \\
\hline $\mathrm{V}_{12}$ & $\begin{array}{l}\text { Community/village security (Being in a peaceful world that has no conflict; Live in a community that is } \\
\text { advanced, secure, and free from invasion) }\end{array}$ \\
\hline $\mathrm{V}_{13}$ & Freedom-independence (Having freedom in all matters, being oneself, depend on oneself) \\
\hline $\mathrm{V}_{14}$ & Happiness-inner harmony (Being satisfied in what one has and is, having a calm and peaceful mind.) \\
\hline $\mathrm{V}_{15}$ & Equality (Being in a society that has equality and justice.) \\
\hline $\mathrm{V}_{16}$ & Family happiness-security (Having a warm, smooth, loving closed and secure family life.) \\
\hline $\mathrm{V}_{17}$ & Pleasure (Having happiness, fun, and recreations with comfort life.) \\
\hline $\mathrm{V}_{18}$ & $\begin{array}{l}\text { Self-controlled, tolerant-restrained } \\
\text { (Self-disciplined, tolerate to all matters) }\end{array}$ \\
\hline $\mathrm{V}_{19}$ & Believe in oneself and Independence (Belief in oneself, self-dependence.) \\
\hline $\mathrm{V}_{20}$ & Responsive to situations-opportunities (Flexible, clever, adjusted to situations and opportunities.) \\
\hline $\mathrm{V}_{21}$ & Contented (Accept one's true status and satisfy with what one has.) \\
\hline $\mathrm{V}_{22}$ & $\begin{array}{l}\text { Educated \& Capable (Search for higher education because education is wealth; possess capability; being } \\
\text { determined and having skills in works.) }\end{array}$ \\
\hline $\mathrm{V}_{23}$ & Calm-cautious (Be calm, restrain emotion, and discreet.) \\
\hline $\mathrm{V}_{24}$ & Caring-considerate (Do not be aggressive, keep relationship and friendship.) \\
\hline $\mathrm{V}_{25}$ & Forgiving and non-vengeful (Be forgiving) \\
\hline $\mathrm{V}_{26}$ & Grateful (Be honest and loyal to others) \\
\hline $\mathrm{V}_{27}$ & Ambitious-hardworking (Set high goals and work hard towards those goals) \\
\hline $\mathrm{V}_{28}$ & Polite-humble (Be polite, humble. Having good manners.) \\
\hline $\mathrm{V}_{29}$ & Obedient-respectful (Respect and listen to the elders who are more experienced and power; Be obedient) \\
\hline $\mathrm{V}_{30}$ & Courageous (Stand for one's opinions and beliefs.) \\
\hline $\mathrm{V}_{31}$ & Honest-sincere (Be truthful and sincere.) \\
\hline $\mathrm{V}_{32}$ & Responsible (Knows one's duties, responsibilities, and be on time.) \\
\hline $\mathrm{V}_{33}$ & Fun-loving, humorous (Like to have fun, witty, humorous. Have a cheerful and relaxed life.) \\
\hline $\mathrm{V}_{34}$ & Imaginative, creative (Be imaginative and artful.) \\
\hline $\mathrm{V}_{35}$ & Clean-neat (Like cleanliness and tidiness.) \\
\hline $\mathrm{V}_{36}$ & Broadminded, open-minded (Be open to opinions and beliefs that are different from one's own.) \\
\hline
\end{tabular}

Source: Adapted from Komin (1991) 


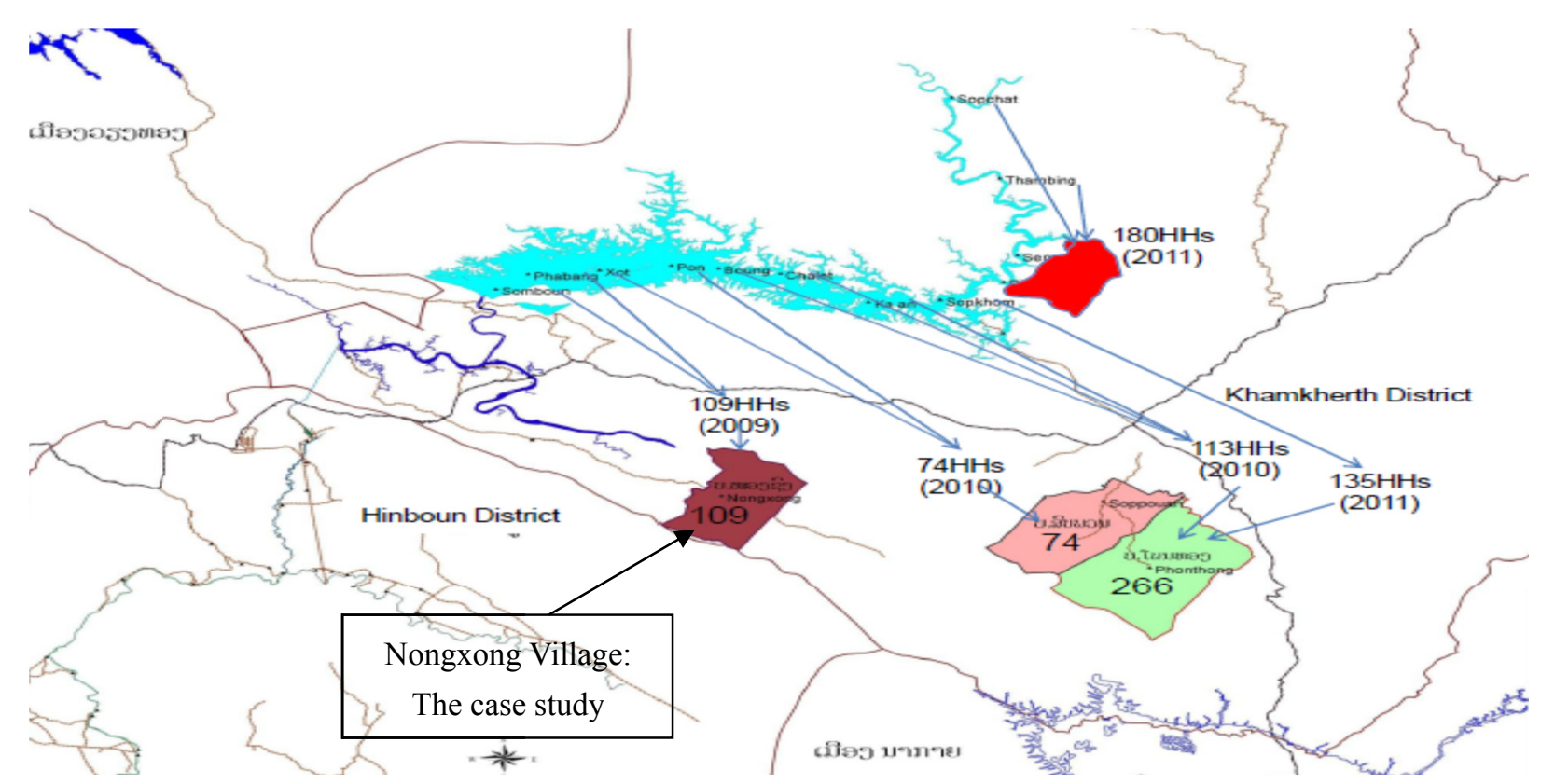

Figure 1. Location of resettlement sites

Source: Field survey, March, 2011; Integrated Extension Program, THXP

\subsection{The Case Study Resettlement}

Resettlement under Thuen Hinboun Expansion Project (THXP) was selected as a case study with the sincere cooperation of the Theun-Hinboun Power Company (THPC). THPC started the expansion of project to improve the seasonal distribution of energy and increase generating capacity in March, 2007 and completed it in 2012. The THXP displaced more than 4,000 people from 12 villages where ethnic groups were mixed.

The dominant ethnic group in this area is Upland-Tai (79\%), of which Tai-Mien and Tai-Pao are the most common. The second largest ethnic group is Hmong (11\%), followed by Phong $(8 \%)$ plus a few Thaveung and $\mathrm{Khmu}$ families (THPC, 2008). Regarding to relocation of people from the project-affected areas, projectaffected people (PAP) have the option to decide either to self-relocate or join resettlement projects. For households preferring self-relocation, the THXP offered one-time final cash compensation. Self-resettlement proposals and plans by individual households (HHs) were reviewed and approved by the THXP and the district authority. The HHs that agreed to join resettlement projects were relocated to four (4) host communities where the basic infrastructure such as health centers, roads, clean water, and electricity were prepared for their living as well as their livelihood restoration. Every resettled household is compensated with a new house built on a piece of land $\left(1,000 \mathrm{~m}^{2}\right), 0.5$ hectare of farmland for cropping, and one hectare of farmland for rice cultivation.

Nongxong village (Figure 1), one of the four resettlement sites, was first completed in the physical relocation of Somboun and Phabang villages with 109 HHs in 2009. Therefore, it was selected for the case study because the peoples' minds would be already settled compared to other resettlement sites. At the Nongxong resettlement site, the population of both host village $(60 \%)$ and resettlers from Somboun $(11 \%)$ and Phabang $(29 \%)$ villages was 1,570 persons (246 households) (Table 2). The ethnicity has diversified from 11 to 18 ethnicities through the resettlement. Particularly, Pao and Phong were resettled as the new majority ethnic groups, into the existent three ethnic groups, while Hmong itself increased in population through the resettlement. In this study, Hmong, Pao, and Phong ethnic groups were focused on as resettlement households.

Table 3 shows the characteristics of sampled HHs by ethnicity. The average age of respondents of Phong ethnic group was 46 years old, while Hmong and Pao ethnic groups were both 38 years old. However, with regard to the average number of years of schooling, Pao ethnic group had 2.9 years, followed by Phong ethnic group with 1.6 years and Hmong ethnic group with 1.1 years. The average size of Hmong HHs was 7.6 persons, Pao HHs 5 persons, and Phong HHs 4.6 persons. The three ethnic groups have different beliefs. All Phong HHs believe in animism, while Pao HHs in both animism and Buddhism and Hmong HHs in animism, Buddhism and Christianity. 
Table 2. Population and households by ethnicity in Nongxong village

\begin{tabular}{|c|c|c|c|c|c|c|}
\hline \multirow{3}{*}{ Ethnicity } & \multicolumn{3}{|c|}{ Households: 246} & \multicolumn{3}{|c|}{ Population: 1,570} \\
\hline & \multirow[t]{2}{*}{ Host village } & \multicolumn{2}{|c|}{ Resettlers } & \multirow[t]{2}{*}{ Host village } & \multicolumn{2}{|c|}{ Resettlers } \\
\hline & & Somboun & Phabang & & Somboun & Phabang \\
\hline Air & - & 1 & - & - & 3 & - \\
\hline Bo & - & 1 & - & - & 7 & - \\
\hline Hmong & 79 & 1 & 30 & 580 & 12 & 239 \\
\hline Kalerng & 4 & - & - & 17 & - & - \\
\hline Khah & 4 & - & - & 20 & - & - \\
\hline Khmu & 13 & - & - & 82 & - & - \\
\hline Khouan & - & - & 1 & - & - & 7 \\
\hline Lao Loum & 1 & - & - & 8 & - & - \\
\hline Man & - & 1 & 7 & - & 5 & 39 \\
\hline Mearn & 2 & 3 & - & 14 & 15 & - \\
\hline Mon & - & - & 1 & - & - & 2 \\
\hline Pao & - & 16 & 26 & - & 81 & 128 \\
\hline Phong & - & 12 & 6 & - & 53 & 34 \\
\hline Phou Thay & 2 & - & - & 17 & - & - \\
\hline Phouan & 2 & - & - & 10 & - & - \\
\hline Tai Toum & 1 & - & - & 5 & - & - \\
\hline Yeng & 7 & - & - & 46 & - & - \\
\hline Yor & 22 & - & - & 135 & - & - \\
\hline Others & - & 1 & 2 & - & - & 11 \\
\hline Total (\%) & 137 & 36 & 73 & $934(60)$ & $176(11)$ & $460(29)$ \\
\hline
\end{tabular}

Source: Field survey, March 2011

Table 3. Characteristics of sample households by ethnicity

\begin{tabular}{|c|c|c|c|c|}
\hline \multicolumn{2}{|c|}{ Households Characteristics } & \multicolumn{3}{|c|}{ Ethnicity } \\
\hline & & Phong & Hmong & $\mathrm{Pao}$ \\
\hline \multirow{2}{*}{ Gender (household) } & Male & 9 & 14 & 16 \\
\hline & Female & 7 & 15 & 13 \\
\hline \multirow{2}{*}{ Age (years old) } & Mean & 46 & 38 & 38 \\
\hline & $\mathrm{SD}$ & 16.85 & 14.88 & 12.54 \\
\hline \multirow{2}{*}{ Schooling (years) } & Mean & 1.6 & 1.1 & 2.9 \\
\hline & SD & 1.83 & 2.82 & 3.17 \\
\hline \multirow{2}{*}{ Household size (person) } & Mean & 4.6 & 7.6 & 5 \\
\hline & SD & 1.633 & 2.718 & 1.439 \\
\hline \multirow{3}{*}{ Beliefs (household) } & Animism & 16 & 16 & 13 \\
\hline & Animism \& Buddhism & 0 & 3 & 16 \\
\hline & Christianity & 0 & 10 & 0 \\
\hline
\end{tabular}

Source: Field surveys, 2011\&2012

\subsection{Data collections and analyses}

Interviews with project managers and staff, focus group interviews with key persons such as village chief, elders, and clan-leaders, and transect walk were conducted to gather existing documents, reports, information and data for research objectives. The survey on values was conducted using a structured interview, mainly by the author with assistance from the clan leader and Hmong language translators. In the case of Hmong ethnic group, respondents were interviewed in Hmong language. The interviews were done at the respondents' houses where they mostly feel comfortable, have more discretion, and have enough time for the interview. On average, it took 
45 minutes for one interview. People were asked how much it was important to their life in Likert scale (from 1 $=$ of very little or no importance to $5=$ of utmost importance). Then the Likert scale data were converted into three levels e.g. low $(1 ; 2=$ Low $)$, medium ( $3=$ Medium), and high $(4 ; 5=$ High). Information and data gathered from the field survey were analyzed qualitatively and quantitatively. Especially, Fisher's exact test was applied to test the statistical significance of difference in the importance level of value among the three ethnic groups.

\section{Results and Discussions}

\subsection{Practical Culture Elements in Planning \& Consultation and Physical Relocation Processes}

In principle, the implementation of resettlement associated with dam constructions consists of three processes: planning \& consultation, physical relocation, and livelihood restoration or livelihood development. Local language such as Lao, Hmong, and Phong is an effective communication tool in meetings. During the consultations, Lao and Hmong languages were used for communication to ensure all PAP participate in meetings. The consultation, particularly relating to cultural desires, is organized on the same day for all ethnic groups but separately in accordance with the ethnicity and gender of PAP, facilitated by locally trained staff. Consultations relating to the livelihood restoration activities at resettlement sites are organized with mixed ethnicity. In the case people (particularly Phong and Hmong ethnic groups) could not understand Lao language, translations of questions and discussions were made during consultations.

Based on interviewing with resettlers and THXP staff and reviewing official documents, the involvement of PAP in resettlement processes (e.g. planning and consultation and physical relocation) is described through three stages: 1) information gathering and dissemination, 2) various consultations, and 3) actual activities. Through these three involvements, the practical culture elements were identified (Table 4). Symbols were structure \& location of the house. Heroes were village headmen who were the same ethnicity as the villagers, elders, clan-leaders, and traditional/spiritual leaders. Rituals were erection of the first post and spirit posts of the house, relocating village and leaving/relocating cemetery ceremonies. Beliefs were Harm-Phi" and "Meau Dee". Recognizing such cultural elements is important because it may help to lessen psychological damages to PAP when they are fulfilled in their spiritual desires.

Table 4. Cultural elements in project affected people's involvement in resettlement processes

\begin{tabular}{ll} 
Process & Consultation \& Planning \\
\hline Symbols & Structure of house, Location of house \\
Heroes & Village chief, elders, clan leaders \& traditional/spiritual leaders \\
& Erection of the first post \& spirit posts of the house, relocating village, leaving/relocating cemetery, \\
Rituals & $\begin{array}{l}\text { new village \& new house entering ceremony } \\
\text { Beliefs }\end{array}$ \\
\hline
\end{tabular}

Source: Field survey, 2011

\subsubsection{Symbols}

Structure of the compensatory house was designed and constructed based on the PAP's current style of house. At the planning process, houses and village layouts were designed and constructed with the active participation of PAP by selecting their preferred house, giving comments and suggesting changes through their own languages. As a result, PAP selected their house design based on the ethnic traditional houses. In addition, the location of compensatory house is important for the resettlers. Most of the resettlers preferred to live near to their relatives and friends who were from the same village and ethnic group. At the consultation, Hmong ethnic group said that they would like to move together as an ethnic group if possible (THPC, 2008). According to the Nongxong village chief, for all ethnics, the location of father's and son's houses must be next to each other. They believe if another person's house is located between their houses, they will have an unhappy life and difficulties in earning a living. Such belief is called 'Harm-phi' which means carrying a human dead body. 


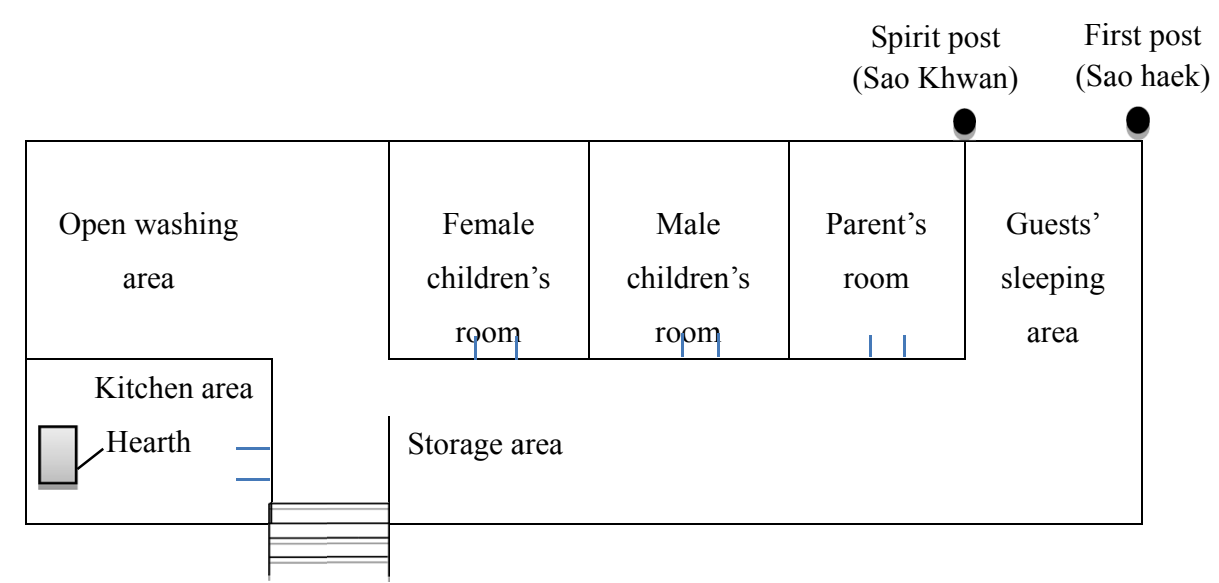

Figure 2. Khmu ethnic group's house layout

Source: Field survey, 2011

Figure 2 shows the house layout of Khmu ethnic group. This design is similar to the Tai-Lao, which Pao ethnic group belongs to. The house is constructed on piles above the ground with ladders and storage areas below the houses for equipment and keeping animals

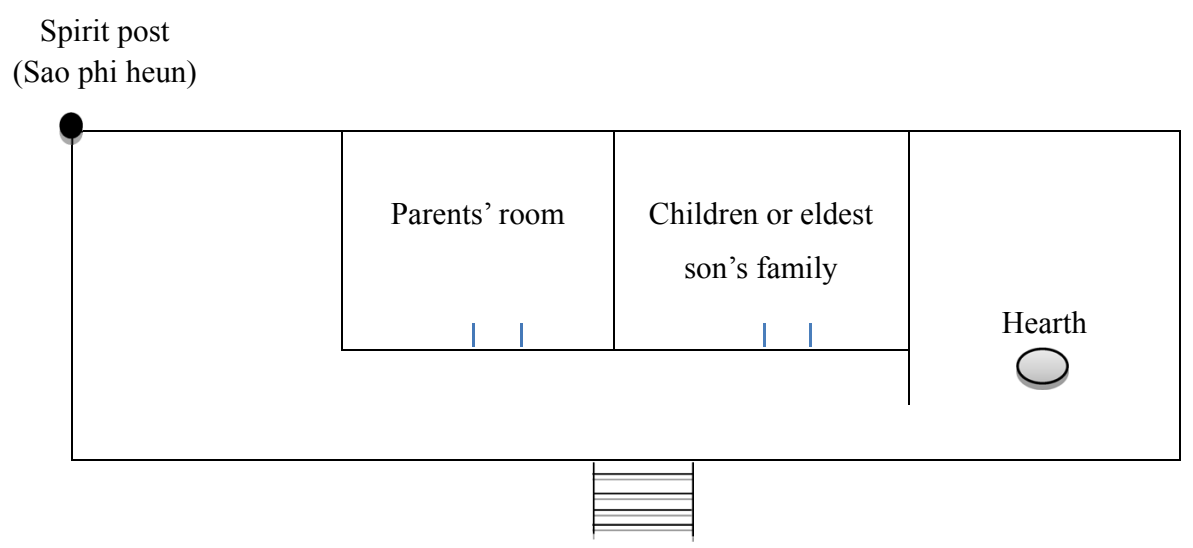

Figure 3. Phong and Thaveung ethnic groups' house layout

Source: Field survey, 2011

Figure 3 shows the house layout of Phong and Thaveung ethnic groups. Their houses lack or have only very small verandas. The area in front of the sleeping rooms serves as a place to socialise and eat.

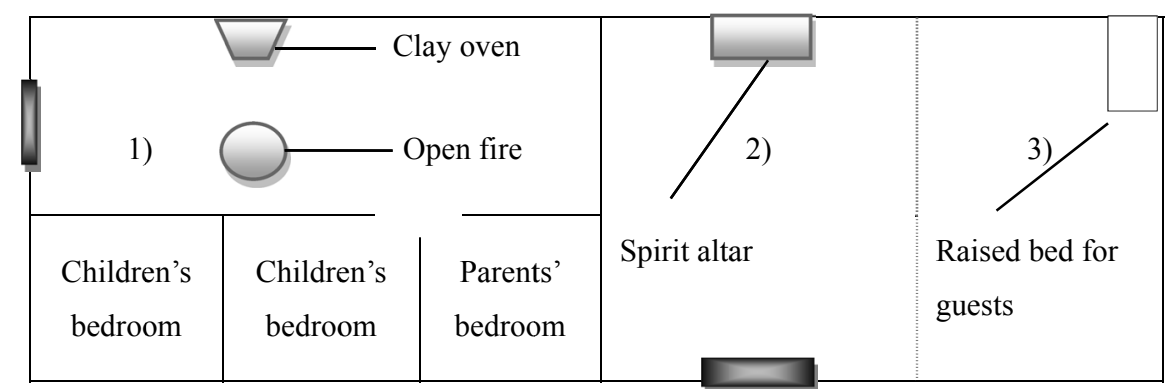

Figure 4. Hmong ethnic groups house layout

Source: Field survey, 2011 
Figure 4 shows the house style of Hmong ethnic group. The house is constructed directly on the earth with no pile. It consists of three main sections: 1) sleeping, cooking, and eating, 2) religious, and 3) socialising and guests sections.

Figures 2, 3, and 4 show two cultural differences in the type of house layout: i.e. the post of house and the spirit altar. According to the direct observation, Pao ethnic group's house has two spirit posts in the east (Figure 2): First post or Sao haek in Lao language and spirit post or Sao Khwan in Lao language. For Phong ethnic group's house, it has only spirit post or sao phi heun in Lao language, in the west (Figure 3) while Hmong ethnic group's houses have no spirit post but has spirit altar inside the houses (Figure 4). The spirit posts between Pao and Phong ethnic has different meaning based on their beliefs. Pao ethnic group refers spirit post to Sao Khwan based on Buddhism (Sao in Lao language means pile and Khwan in Lao language is synonymous with the word soul in English). But Phong ethnic group refers spirit post to Sao Phi Heun based on Animism (Phi in Lao language means ghosh and heun means house in English). As shown in Table 3, it shows that Pao and Phong ethnic groups view and mean the same thing in different ways based on their different beliefs.

\subsubsection{Heroes}

Heroes among three ethnic groups are different. According to the consultation staff and a manager of social development division of THXP, for Pao ethnic group, elders and village chief are highly respected, while religious/spiritual leaders are the most respected for Hmong ethnic group. However, there are no particular heroes for Phong ethnic group. According to interviews with Phong ethnic respondents, they said that every Phong person has his own individual heroes who are his relatives.

In principle in Lao rural society, the headman and the council of elders preside over all ceremonies involving births, marriage and death, as well as some rituals to honor the village guardian spirit in rural Lao communities (Schliesinger, 2003). During the planning and consultation processes, PAP expressed the village's spiritual desire and presided over actual ceremonies such as rituals in the physical relocation process. For instance, on the day of physical relocation, the eldest persons of the village leave the house first and then the ordinary persons follow. In the case of eldest person/HH not leading in moving, the implementation of physical relocation is not possible. In this respect, heroes play a very important role in such situations.

\subsubsection{Rituals}

The four necessary ceremonies needed to be implemented are: 1) erection of the first post and spirit posts of the house, 2) relocating the village ceremony, 3) leaving/relocating the cemetery ceremonies, and 4) new village and new house entering ceremony. The preferences of cultural ceremonies are delivered during consultation and planning and physical relocation processes. The THXP provided the financial support to compensate the cost of all the ceremonies of the villages approved by the district authority considerations.

The erection of the first post and spirit posts of the house were conducted in the case of Phong and Pao ethnic groups but were not necessary for Hmong ethnic group. This ceremony was conducted based on the preferred day of the individual house owner before constructing the house. In relocating a village, the territorial spirit (Phi Meuang/Phi Ban) needs to be informed, and all villagers are expected to participate before the village will be relocated to a new site. THXP provided necessary items for territorial spirit informing: pig: one (1) head, chicken: Two (2) heads, Lao Hai: Two (2) jars, some candles, tea, and white paper. Leaving/relocating the cemetery is another necessary ritual to be implemented. The financial support for this ceremony has two categories: a child's tomb is 450,000 kip (approximately US\$ 50) while an adult's tomb is 1,250,000 kip (approximately US\$ 150). For Hmong ethnic group (in Phabang village), each household performed the ceremony individually while other ethnics conducted such ceremonies all together at once. For the new house entering ceremony, each house received one chicken. For other necessary items to perform ceremonies, house owners were responsible for themselves (THPC, 2009).

\subsubsection{Beliefs}

There was an important belief associated in the processes of allocating a hectare of compensatory rice field for resettled HHs during the process of dividing the compensatory rice field in 2011. Such belief is called "Harm-Phi" in Lao language (In English, "Carrying Death Body"). According to a focused group interviews with village chiefs, clan-leaders of Hmong and of Phong ethnic groups and elders, the rice field must be located along the same lines of their belief when allocating the house location. Therefore, it is impossible for them to accept the land if not the case.

Figure 5 shows seven cases of land location against the "Harm-Phi" belief. PAP reported that they would not accept the compensatory house and cultivated land if it falls in any of these cases which are against their belief 
reasoning that they will face many unfortunate events in the future.

Another local belief directly associated with the resettlement process of physical relations is called "Meau Dee". "Meau Dee" in Lao language means a good day in English. Villagers decided "Meau Dee" or the actual day when they move to the resettlement site according to their beliefs. According to the interviews and personal communication with elders, all HHs moved into the resettlement village in the same year, but on different dates in April and in June, 2009. As a result, the completion of physical relocation of all HHs from the original village to the resettlement site was achieved with $71 \mathrm{HHs}$ in April and $38 \mathrm{HHs}$ in June. At first, villagers decided the month. Both April and June are the 5th and 7th month of the year in the lunar calendar 2009. It is believed that entering a new house must be in an odd month. In the Lao proverb, it is said "Keek You Koo Nee". (In English, Keek means odd number; You means stay; Koo means the even number, and Nee means be apart.).Secondly, villagers decide the day. In a week, there is a particular day that villagers want to move. In the case of Hmong ethnic group, Thursday is the best day for moving and entering the new houses. In an interview with a Hmong clan leader, he said, "Our ancestors have taught us that when we move house or relocate, the best day is Thursdays. Thursday is peaceful and sincere. It will bring you a happy life at your new house."

\begin{tabular}{|c|c|c|c|c|c|}
\hline Case: 1 & Father's land/house & \multicolumn{3}{|c|}{ Mr. X's land/house } & Son's land/house \\
\hline Case: 2 & Mr.A's land/house & \multicolumn{3}{|c|}{ Mr. X's land/house } & Mr.A's land/house \\
\hline Case: 3 & Mr.A's land/house & \multicolumn{3}{|c|}{ Forest } & Mr.A's land/house \\
\hline Case: 4 & Mr.A's land/house & \multicolumn{3}{|c|}{ River/steam(Width $>3$ meters) } & Mr.A's land/house \\
\hline \multirow{2}{*}{ Case: 5} & Father's land/house & Mr. B's land/house & \multicolumn{2}{|c|}{ Mr. C's land/house } & Mr. D's land/house \\
\hline & Mr. E's land/house & Mr. F's land/house & \multicolumn{2}{|c|}{ Mr. G's land/house } & Son's land/house \\
\hline \multirow{2}{*}{ Case: 6} & Mr.A's land/house & Mr. B's land/house & \multicolumn{2}{|c|}{ Mr. C's land/house } & Mr. D's land/house \\
\hline & Mr. E's land/house & Mr. F's land/house & \multicolumn{2}{|c|}{ Mr. G's land/house } & Mr.A's land/house \\
\hline Case: 7 & Father's land/house & Distance $>100$ meters & Mr. X's land & Distance $>100$ meters & Son's land/house \\
\hline
\end{tabular}

Figure 5. Seven cases of location of cultivated lands/of houses against local people's belief

Source: Field survey, November, 2011

Note: The $2^{\text {nd }}$ and $4^{\text {th }}$ columns in grey colour represent the one hectare of compensatory rice field $/ 1,000 \mathrm{~m}^{2}$ of land for build house for resettlers. The hectare of compensatory rice field is separated into two parts in some cases because available land particularly that is suitable for cultivating rice is limited when large amount of resettlers refluxed into the community.

\subsection{Senses of Values behide the Cultural Elements}

That the cultural elements such as symbol, hero, ritual and beliefs have played a practical and significant role in the consensus formation during the consultation \& planning and physical relocation processes. However, the degree of sense of value related to symbol, ritual and belief is different among ethnic groups while the degree of sense of value related to hero is the same among ethnic groups.

According to the results from Fisher's Exact Test, there were 19 values out of 36 values which were statistically significant different among the three ethnic groups at alpha 0.05 (Table 6). In addition, the results indicated that out of 36 values, 17 values were not statistically significant different at alpha 0.05 among the three ethnic groups (Appendix 1). Therefore, it can be concluded that in overall different ethnic groups have similarities and some differences in terms of values which are the fundamental part of the culture.

Table 6 shows different ethnic groups have different levels of sense of value related to religious-spiritual life to guide their lives $\left(\mathrm{V}_{8}\right)$. This sense of value is embodied in cultural elements i.e. symbols, rituals, and beliefs in the resettlement process, particularly consultation and planning and physical relocation as it was described in 3.1.1, 3.1.3, and 3.1.4. Based on these findings, it can be concluded cultural elements (e.g. symbols, rituals and beliefs) 
are important for all three ethnic groups with different degrees.

On the other hand, Appendix 1 shows that no difference in level of sense of value related to obedient-respectful value $\left(\mathrm{V}_{29}\right)$ among the three ethnic groups. Such value is related to the cultural element of heroes. According to finding 3.1.2, it was seen that different ethnic groups have their own heroes. Based on these two findings, it can be concluded that different ethnic groups had the same degree of sense of value relating to cultural element i.e. heroes. It implies that in each ethnic group people are obedient and respectful to their own heroes at the same degree, even though heroes are varied from one ethnic group to another. The previous study of Alton and Rattanavong (2004) stated that when an intervention was planned in rural areas of Laos, the cultural consequences of these interventions should be anticipated as much as possible. Local villagers, including respected elders or clan leaders with indigenous knowledge should be consulted (Alton \& Rattanavong, 2004). The heroes, such a village headmen with the same ethnicity, council of elders, clan-leaders, and traditional/spiritual leaders play a key role because they preside over all important events of people's lives such as birth, marriage and death in the community.

Table 6. Frequency distribution of values' importance degree by ethnicity in 19 values (with significant differences among ethnic groups)

\begin{tabular}{|c|c|c|c|c|c|c|}
\hline Code & Value & Ethnicity & Low & Medium & High & Fisher's Exact Test $(\mathrm{P}<0.05)$ \\
\hline \multirow{3}{*}{$\mathrm{V}_{1}$} & \multirow{3}{*}{$\begin{array}{l}\text { Brotherhood spirit \& Interdependent, } \\
\text { mutually helpful, Kind-helpful }\end{array}$} & Hmong & 0 & 0 & 29 & \multirow{3}{*}{0.000} \\
\hline & & Pao & 0 & 19 & 10 & \\
\hline & & Phong & 2 & 1 & 13 & \\
\hline \multirow{3}{*}{$\mathrm{V}_{2}$} & \multirow{3}{*}{ Social recognition } & Hmong & 0 & 2 & 27 & \multirow{3}{*}{0.001} \\
\hline & & Pao & 1 & 14 & 14 & \\
\hline & & Phong & 1 & 3 & 12 & \\
\hline \multirow{3}{*}{$\mathrm{V}_{3}$} & \multirow{3}{*}{ An exciting life } & Hmong & 1 & 2 & 26 & \multirow{3}{*}{0.005} \\
\hline & & $\mathrm{Pao}$ & 3 & 11 & 15 & \\
\hline & & Phong & 1 & 8 & 7 & \\
\hline \multirow{3}{*}{$\mathrm{V}_{5}$} & \multirow{3}{*}{ True friendship } & Hmong & 0 & 12 & 17 & \multirow{3}{*}{0.033} \\
\hline & & $\mathrm{Pao}$ & 0 & 18 & 11 & \\
\hline & & Phong & 1 & 4 & 11 & \\
\hline \multirow{3}{*}{$\mathrm{V}_{8}$} & \multirow{3}{*}{$\begin{array}{l}\text { Religious-spiritual life to guide in a } \\
\text { living }\end{array}$} & Hmong & 0 & 3 & 26 & \multirow{3}{*}{0.003} \\
\hline & & $\mathrm{Pao}$ & 0 & 7 & 22 & \\
\hline & & Phong & 1 & 3 & 12 & \\
\hline \multirow{3}{*}{$\mathrm{V}_{9}$} & \multirow{3}{*}{ Social relation } & Hmong & 0 & 0 & 29 & \multirow{3}{*}{0.009} \\
\hline & & Pao & 0 & 2 & 27 & \\
\hline & & Phong & 1 & 2 & 13 & \\
\hline \multirow{3}{*}{$\mathrm{V}_{12}$} & \multirow{3}{*}{ Community/village security } & Hmong & 0 & 0 & 29 & \multirow{3}{*}{0.046} \\
\hline & & Pao & 0 & 6 & 23 & \\
\hline & & Phong & 0 & 3 & 13 & \\
\hline \multirow{3}{*}{$\mathrm{V}_{13}$} & \multirow{3}{*}{ Freedom-independence } & Hmong & 0 & 6 & 23 & \multirow{3}{*}{0.004} \\
\hline & & Pao & 3 & 16 & 10 & \\
\hline & & Phong & 2 & 8 & 6 & \\
\hline \multirow{3}{*}{$\mathrm{V}_{14}$} & \multirow{3}{*}{ Happiness-inner harmony } & Hmong & 0 & 1 & 28 & \multirow{3}{*}{0.001} \\
\hline & & Pao & 2 & 12 & 15 & \\
\hline & & Phong & 0 & 4 & 12 & \\
\hline \multirow{2}{*}{$\mathrm{V}_{19}$} & \multirow{2}{*}{ Believe in oneself and Independence } & Hmong & 0 & 2 & 27 & \multirow{2}{*}{0.000} \\
\hline & & Pao & 0 & 8 & 21 & \\
\hline
\end{tabular}




\begin{tabular}{|c|c|c|c|c|c|c|}
\hline & & Phong & 1 & 9 & 6 & \\
\hline & & Hmong & 0 & 4 & 25 & \\
\hline \multirow[t]{3}{*}{$\mathrm{V}_{20}$} & Responsive to situations-opportunities & Pao & 0 & 14 & 15 & 0.002 \\
\hline & & Phong & 0 & 10 & 6 & \\
\hline & & Hmong & 0 & 3 & 26 & \\
\hline \multirow[t]{3}{*}{$\mathrm{V}_{21}$} & Contented & Pao & 0 & 12 & 17 & 0.027 \\
\hline & & Phong & 0 & 5 & 11 & \\
\hline & & Hmong & 1 & 2 & 26 & \\
\hline \multirow[t]{3}{*}{$\mathrm{V}_{23}$} & Calm-cautious & Pao & 1 & 13 & 15 & 0.009 \\
\hline & & Phong & 0 & 7 & 9 & \\
\hline & & Hmong & 0 & 3 & 26 & \\
\hline \multirow[t]{3}{*}{$\mathrm{V}_{24}$} & Caring-considerate & $\mathrm{Pao}$ & 2 & 11 & 16 & 0.030 \\
\hline & & Phong & 0 & 4 & 12 & \\
\hline & & Hmong & 0 & 1 & 28 & \\
\hline \multirow[t]{3}{*}{$\mathrm{V}_{27}$} & Ambitious-hardworking & Pao & 0 & 6 & 23 & 0.039 \\
\hline & & Phong & 0 & 5 & 11 & \\
\hline & & Hmong & 0 & 4 & 25 & \\
\hline \multirow[t]{3}{*}{$\mathrm{V}_{28}$} & Polite-humble & Pao & 0 & 8 & 21 & 0.010 \\
\hline & & Phong & 0 & 9 & 7 & \\
\hline & & Hmong & 0 & 4 & 25 & \\
\hline \multirow[t]{3}{*}{$\mathrm{V}_{34}$} & Imaginative, creative & Pao & 0 & 11 & 18 & 0.019 \\
\hline & & Phong & 0 & 8 & 8 & \\
\hline & & Hmong & 0 & 4 & 25 & \\
\hline \multirow[t]{2}{*}{$\mathrm{V}_{35}$} & Clean-neat & Pao & 0 & 13 & 16 & 0.032 \\
\hline & & Phong & 0 & 6 & 10 & \\
\hline
\end{tabular}

Source: Author's computation, 2012

\section{Conclusion}

Through PAP's involvements in planning and consultation and physical relocation processes, the cultural elements were identified: Symbols are structure \& location of the house; Heroes are village headmen who are the same ethnicity as the villagers, elders, clan-leaders, and traditional/spiritual leaders; Rituals are erection of the first post and spirit posts of the house, relocating village and leaving/relocating cemetery ceremonies; and Beliefs are "Harm-Phi"; "Meau Dee". There are significant differences in practices as well as in senses of values related to those cultural elements among Phong, Hmong, and Pao ethnic groups. Symbols, rituals, and beliefs are important to different ethnic groups with different degrees while heroes are important to them with the same degree.

The results from this study suggest that the implementation of resettlement project where ethnic groups are mixed; cultural consideration must be taken into project designing. This consideration is necessary for project implementers because it can increase the efficiency of project implementation especially in planning \& consultation and physical relocation processes. In addition, this cultural consideration is a must for all development interventions to be concerned because culture (symbols, heroes, rituals, beliefs and value) is the foundation of PAP's life that are directly affected by all kind of state development planning.

\section{References}

Alton, C., \& Rattanavong, H. (2004). Service Delivery and Resettlement: Options for Development Planning. Vientiane: United Nation Development Program.

Asian Development Bank. (2008). Ethnic Minority Development Framework: Lao People's Democratic 
Republic-Sustainable Natural Resource Management and Productivity Enhancement Project. Vientiane: Asian Development Bank.

Asian Development Bank. (2012). Asian Development Bank \& Lao People's Democratic Republic: Face Sheet. Retrieved June 12, 2013, from http://www.adb.org/sites/default/files/pub/2013/LAO.pdf

Baird, I. G. \& Shoemaker, B. (2005). Aiding or Abetting? Internal Resettlement and International Aid Agencies in Laos. Canada: Probe International.

Chamberlain, J. R. (2007). Participatory Poverty Assessment II: Lao People's Democratic Republic. Vientiane: National Statistic Center.

Chazée, L. (1999). The peoples of Laos: Rural and Ethnic Diversities. Bangkok: White Lotus.

Collins, R. (Ed.). (1985). The Three Sociological Traditions. New York: Oxford University Press.

Daviau, S. (2006). Rural Development in Mountainous Areas of Northern Lao PDR: Follow up study on relocation of Khamu and Rmeet communities in Nalae district, Luang Namtha provice, Lao PDR. German Technical Cooperation(GTZ).

European Union (EU). (2011). Resettlement in Laos: Final Report 6 August 2011 (Unpublished).

Evrard, O., \& Goudineau, Y. (2004). Planned Resettlement, Unexpected Migrations and Cultural Trauma in Laos. Development and Changes, 35, 937-962. http://dx.doi.org/10.1111/j.1467-7660.2004.00387.x

Field, A. (2005). Discovering Statitistices using SPSS. London: SAGE.

Hofstede, G., Hofstede, G. J., \& Minkov, M. (2010). Culture and Organizations: Software of the Mind. USA: Mc Craw Hill.

International River. (1999). Power Surge: The Impact of Rapid Dam Development in Laos. International River.

Komin, S. (1991). Psychology of the Thai People. Bangkok: National Institute of Development Administration.

Laos. (2005a). PM's Decree No.192: Decree on the Compensation and Resettlement of the Development Projec. Vientiane: Government of Lao PDR.

Laos. (2005b). The Ethnic Groups in Lao PDR. Vientiane: Lao National Front for Construction.

Laos. (2008). Socio-Economic ATLAS of the Lao PDR. Vientiane: National Statistic Center.

Lyttleton, C., Cohen, P., Rattanavong, H., Thongkhamhane, B., \& Sisaengrat, S., (Eds.).(2004) Watermelons, bars and trucks: dangerous intersections in Northwest Lao PDR. Institute for Cultural Research of Laos and Macquarie University.

Rokeach, M. (1973). The nature of human values. New York: Free Press.

Rokeach, M. (1979). Understanding Human Values: Individual and Societal. New York: Free Press.

Schliesinger, J. (2003). Ethnic Groups of Laos Volume 2: Profile of Austro-Asiatic Speaking People. Bangkok: White Lotus Co Ltd.

Shawyun, T., \& Tanchaisak, K. (2006). A better understading of the core values of Thai undergraduate. Retrieved January 29, 2013, from http://www.qa.au.edu/page2/research/TeayShawyunANDKrisdaTacchaisakSEAAIR2005FullPaer.pdf

Theun Hinbou Power Campany. (2008). Theun-Hinboun Expansion Project: Resettlement Action Plan, Part 2-Reservior and Host Village Areas. Theun Hinboun Power Company.

Theun Hinbou Power Campany. (2009). Theun-Hinboun Expansion Project:Meeting minute on Consultation of Leaving Cemetery Ceremony of Sonboun Village (unpublished).

Theun Hinbou Power Campany. (2009). Theun-Hinboun Expansion Project:Meeting minute on Consultation of territorial spirit informing ceremony of Sonboun Village (unpublished).

World Bank. (2010). Lao PDR Development Report: Natural Resources Management for Sustainable Development: Hydropower and Mining. World Bank. 


\section{Appendix 1}

Frequency distribution of values' importance degree by ethnicity (with no significant differences among ethnic groups)

\begin{tabular}{|c|c|c|c|c|c|c|}
\hline Code & Values & Ethnicity & Low & Medium & High & Fisher's Exact Test $(\mathrm{P}>0.05)$ \\
\hline & & Hmong & 0 & 1 & 28 & \\
\hline \multirow[t]{3}{*}{$\mathrm{V}_{4}$} & A comfortable life \& status-wealth & $\mathrm{Pao}$ & 0 & 7 & 22 & 0.066 \\
\hline & & Phong & 0 & 3 & 13 & \\
\hline & & Hmong & 14 & 10 & 5 & \\
\hline \multirow[t]{3}{*}{$\mathrm{V}_{6}$} & A beauty and abundance of nature & Pao & 11 & 12 & 6 & 0.220 \\
\hline & & Phong & 12 & 3 & 1 & \\
\hline & & Hmong & 0 & 6 & 23 & \\
\hline \multirow[t]{3}{*}{$\mathrm{V}_{7}$} & Mature love with the same ethnicity & Pao & 0 & 9 & 20 & 0.160 \\
\hline & & Phong & 0 & 1 & 15 & \\
\hline & & Hmong & 0 & 2 & 27 & \\
\hline \multirow[t]{3}{*}{$\mathrm{V}_{10}$} & Wisdom-knowledge & Pao & 0 & 2 & 27 & 0.361 \\
\hline & & Phong & 1 & 2 & 13 & \\
\hline & & Hmong & 0 & 6 & 23 & \\
\hline \multirow[t]{3}{*}{$\mathrm{V}_{11}$} & Self-esteem & Pao & 3 & 7 & 19 & 0.426 \\
\hline & & Phong & 1 & 5 & 10 & \\
\hline & & Hmong & 0 & 4 & 25 & \\
\hline \multirow[t]{3}{*}{$\mathrm{V}_{15}$} & Equality & $\mathrm{Pao}$ & 0 & 7 & 22 & 0.386 \\
\hline & & Phong & 0 & 5 & 11 & \\
\hline & & Hmong & 0 & 0 & 29 & \\
\hline \multirow[t]{3}{*}{$\mathrm{V}_{16}$} & Family happiness-security & Pao & 1 & 4 & 24 & 0.158 \\
\hline & & Phong & 0 & 2 & 14 & \\
\hline & & Hmong & 0 & 7 & 22 & \\
\hline \multirow[t]{3}{*}{$\mathrm{V}_{17}$} & Pleasure & Pao & 4 & 9 & 16 & 0.117 \\
\hline & & Phong & 0 & 5 & 11 & \\
\hline & & Hmong & 0 & 9 & 20 & \\
\hline \multirow[t]{3}{*}{$\mathrm{V}_{18}$} & Self-controlled, tolerant-restrained & Pao & 0 & 10 & 19 & 0.950 \\
\hline & & Phong & 0 & 6 & 10 & \\
\hline & & Hmong & 0 & 3 & 29 & \\
\hline \multirow[t]{3}{*}{$\mathrm{V}_{22}$} & Educated \& Capable & Pao & 0 & 6 & 23 & 0.58 \\
\hline & & Phong & 2 & 3 & 11 & \\
\hline & & Hmong & 0 & 9 & 20 & \\
\hline \multirow[t]{3}{*}{$\mathrm{V}_{25}$} & Forgiving and non-vengeful & Pao & 3 & 12 & 14 & 0.166 \\
\hline & & Phong & 0 & 6 & 11 & \\
\hline & & Hmong & 0 & 2 & 27 & \\
\hline \multirow[t]{3}{*}{$\mathrm{V}_{26}$} & Grateful & $\mathrm{Pao}$ & 0 & 3 & 26 & 0.881 \\
\hline & & Phong & 0 & 2 & 14 & \\
\hline & & Hmong & 0 & 3 & 26 & \\
\hline \multirow[t]{3}{*}{$\mathrm{V}_{29}$} & Obedient-respectful & Pao & 0 & 6 & 23 & 0.457 \\
\hline & & Phong & 0 & 4 & 12 & \\
\hline & & Hmong & 0 & 2 & 27 & \\
\hline \multirow[t]{3}{*}{$\mathrm{V}_{30}$} & Courageous & Pao & 0 & 6 & 23 & 0.249 \\
\hline & & Phong & 0 & 4 & 12 & \\
\hline & & Hmong & 0 & 3 & 26 & \\
\hline \multirow[t]{3}{*}{$\mathrm{V}_{31}$} & Honest-sincere & Pao & 0 & 6 & 23 & 0.425 \\
\hline & & Phong & 0 & 1 & 15 & \\
\hline & & Hmong & 0 & 2 & 27 & \\
\hline \multirow[t]{3}{*}{$V_{32}$} & Responsible & $\mathrm{Pao}$ & 1 & 6 & 22 & 0.310 \\
\hline & & Phong & 0 & 4 & 12 & \\
\hline & & Hmong & 0 & 8 & 21 & \\
\hline \multirow[t]{3}{*}{$\mathrm{V}_{33}$} & Fun-loving, humorous & Pao & 1 & 8 & 20 & 1.000 \\
\hline & & Phong & 0 & 4 & 12 & \\
\hline & & Hmong & 0 & 4 & 25 & \\
\hline \multirow[t]{2}{*}{$\mathrm{V}_{36}$} & Broadminded, open-minded & Pao & 2 & 9 & 18 & 0.170 \\
\hline & & Phong & 0 & 4 & 12 & \\
\hline
\end{tabular}

Source: Author's computation, 2012 


\section{Copyrights}

Copyright for this article is retained by the author(s), with first publication rights granted to the journal.

This is an open-access article distributed under the terms and conditions of the Creative Commons Attribution license (http://creativecommons.org/licenses/by/3.0/). 